\title{
Conservation Agriculture Based Tillage Options for Rabi Crops Cultivation in Eastern India: Effects on Productivity and Profitability
}

\author{
Shweta Kumari", Sanjay Kumar, Asheesh Chaurasiya, Swaraj Kumar Dutta, \\ Amit Pradhan and Subrat Keshori Behera
}

Department of Agronomy, BAU, Bhagalpur - 813210, India

*Corresponding author

\section{A B S T R A C T}

In conventional tillage, the traditional practice of opening and turning the soil greatly contributes towards the quick oxidation of organic matter in the soil, quantitative loss of residual soil moisture and high labour and energy input thereby resulting in the poor economic returns for the farmers. However, in some situations tillage causes the soil degradation which results into development of compacted soil having low soil organic carbon (SOC) and restricted drainage. So, the experiment was conducted to specify the

Keywords

Conventional tillage, Soil organic carbon $\mathrm{B}: \mathrm{C}$ ratio

Article Info

Accepted:

12 June 2019 Available Online: 10 July 2019 tillage practices which can keep protecting the soil healthy for longer period. This experiment was devised to evaluate the effect of long term CA practices like zero tillage and permanent beds on production, productivity and economics of the $5^{\text {th }}$ year rabi season crops as compared to their performance against the business as usual practice i.e., conventional tillage practice for different Rabi season crops. The experiment had a split plot design, replicated thrice with three main plot treatments viz. zero tillage (ZT), conventional tillage (CT) and permanent bed (PB) and four sub plot treatment viz. wheat, rabi maize, mustard and chickpea. The results revealed that higher grain yield of wheat was recorded under PB (5488 $\left.\mathrm{kg} \mathrm{ha}^{-1}\right)$ over ZT and CT while, higher grain yield of rabi maize (11279 kg ha $\left.{ }^{-1}\right)$, mustard $\left(970 \mathrm{~kg} \mathrm{ha}^{-1}\right)$ and chickpea $\left(1936 \mathrm{~kg} \mathrm{ha}^{-1}\right)$ was recorded in ZT over CT. The highest net return (Rs 64,779 ha ${ }^{-1}$ ), and B: C ratio (2.09) was recorded under ZT which was at par with PB (Rs 61,789 ha $\mathrm{ha}^{-1}$ and 2.02). Among rabi crops, highest net return was recorded in maize (Rs. 1,00,509 ha-1) followed by chickpea (Rs. 57,975 ha$\left.{ }^{1}\right)$ while B:C ratio was highest for chickpea (2.70) followed by rabi maize (2.05), wheat (1.74) and mustard (0.77). The experiment shows that conservation agriculture-based Zero tillage and permanent bed tillage practices along with residue retention resulted in significant increase in biomass production and productivity of rabi crops with higher net returns and $\mathrm{B}: \mathrm{C}$ ratio than conventional tillage practice.

\section{Introduction}

Bihar is one of the most important states in the Eastern India and Middle Indo Gangetic plains in terms of crop production with its burgeoning population of 104 million people
(MoA 2013) and steadily increasing population efforts to enhance agricultural productivity is utmost important to ensure food security. Rice - Wheat is the dominant cropping system of the state with wheat being the major rabi season crop. However, in the 
last few years' maize crop has emerged as a potential replacement for wheat during the rabi season due to its temporal suitability, profitability (Ali et al., 2009) and market demand (Pandey et al., 2008; Gill et al., 2008). In Bihar, generally rabi crops grown after the harvest of predominant kharif rice or kharif maize which is determined by distribution of the monsoon because, sometimes due to delayed monsoon or due to long duration rice cultivars harvesting of the rice gets delayed resulting sowing of the next rabi crops gets delayed due to adoption of conventional tillage by the farmers. Tillage is one of the fundamental agro-technical operations, performed to achieve soil environment favorable for crop growth and development. In conventional tillage, the traditional practice of opening and turning the soil greatly contributes towards the quick oxidation of organic matter in the soil (Gathala et al., 2011), quantitative loss of residual soil moisture and high labour and energy input thereby resulting in the poor economic returns for the farmers (Aryal et al., 2015). However, in some situations tillage can lead to soil degradation which results into development of compacted soil having low soil organic carbon (SOC) and restricted drainage. Conventional tillage (CT) practices being highly intensive in nature, leads to gradual decline in soil organic matter through accelerated oxidation, with a consequent reduction in the capacity of the soil to regulate water and nutrient supplies to plants. The tillage operations are energy and input intensive as well as create difficulty in the timely seeding of the succeeding crop (Bhushan et al., 2008; Jat et al., 2009). CT for crop production needs higher labour and fuel cost which results in lower economic returns to the growers pushing them towards continuous trap of poverty (Jat et al., 2012). Moreover, CT along with faulty agricultural practices such as deforestation, selection of inappropriate crop sequences and burning of crop residues etc. directly and indirectly reported to be associated with wide range of agricultural challenges such as water and labour crises, extensive land degradation, poor soil fertility and agricultural related climate change which put larger pressure on available agricultural land in order to feed the ever rising human and animal population (Stocking and Murnaghan, 2001). Therefore, in current scenario there is an urgent need to identify, demonstrate and to recommend tillage practices which are alternate to $\mathrm{CT}$ systems and can deal with the above mentioned challenges, so that agriculture may come out as a source of farmers' prosperity.

Conservation agriculture (CA) based crop management practices such as zero tillage (ZT) and permanent beds (PB) along with crop diversification is quite helpful to maximize the yield by utilizing the soil and other natural resources without creating a negative impact on the environment. Conservation agriculture (CA) based crop management technologies have been intensified to overcome the aforesaid problems. It mainly refers to the crop establishment through minimal disturbance of soil, retaining crop residues on the soil surface and spatial variability of crops to derive maximum input benefit (Hassan et al., 2005) and minimize the adverse footprint on soil health. The main component of CA being crop establishment on flat surface without tillage i.e. zero tillage (ZT) or on permanent raised beds (PB) without any tillage. ZT and PB involving lesser soil disturbance, soil cover and cost-effective cropping sequences, found to be helpful in lowering the production cost in addition to providing environmental services in terms of lower carbon emission and better soil health. ZT and PB has been reported to decrease biological oxidation of SOC, increases water holding capacity, prevents land degradation by lowering the intensity of soil erosion (Six et al., 2002). This 
has led to a major shift in adoption of ZT wheat after kharif crop. Most of the research work on conservation agriculture mainly concentrated in the Western part of IGP where wheat under CA practice has been intensively documented. The middle and Eastern IGP with a much different agro ecological scenario, the efficacy of CA practices on performance of rabi season crops is yet to be explored. So, precise information on the potential benefits of CA adoption for the region is scarce. So, this experiment was conducted for conservation agriculture based tillage options for rabi crop cultivation in Eastern India. Our main focus is to change the traditional tillage practices with some new tillage practices which can enhance economic condition of farmers as well as improve the soil health for longer period. The results from the experiment shall also help to understand the likely adoption benefits of CA for different cool season crops in the region.

\section{Materials and Methods}

A field experiment was conducted during the Rabi season of 2017-18 on "Conservation agriculture based tillage options for rabi crop cultivation in Eastern India" at the research farm of Bihar Agricultural University, Sabour, Bhagalpur, Bihar to assess the effects of different tillage methods on growth, productivity and profitability of Rabi crops. The climatic conditions under which the experiment was carried out, the materials used and techniques employed during the course of investigation are described in this chapter.

\section{Experimental site}

The experiment was carried out at experimental farm of Bihar Agricultural University, Sabour, Bhagalpur, Bihar (India) during 2017-18 in rabi season. The experimental plots had uniform topography with homogeneous fertility.

\section{Weather condition of experimental site}

The geographical location of the experimental site of Bihar Agricultural University, Sabour comes under the Middle Gangetic plain region of Agro-climatic Zone III A. It is situated at longitude $87^{\circ} 2^{\prime} 45^{\prime \prime}$ East and latitude $25^{\circ} 15^{\prime} 4^{\prime \prime}$ North at an altitude of 37.19 meters above mean sea level. The climatic condition of this place is tropical to subtropical of somewhat semi-arid in nature and is characterized by very dry summer, moderate rainfall and very cold winter.

\section{Rainfall and temperature}

The average rainfall is about $1407 \mathrm{~mm}$ (10years average) which is unimodal type mostly precipitating during middle of June to middle of October, where potential evapotranspiration is lower than the rainfall. The minimum and maximum day temperature is $18^{\circ} \mathrm{C}$ and $35^{\circ} \mathrm{C}$ during summer season whereas $15^{\circ} \mathrm{C}$ and $25^{\circ} \mathrm{C}$ are the minimum and maximum day temperature during winter season respectively. During the crop season there was cool and bright climate prevails throughout the dry season.

\section{Weather condition during crop season}

The data on weather parameters such as distribution of rainfall, maximum and minimum temperature and relative humidity recorded from meteorological observatory of Bihar Agricultural University, Sabour during the crop season are graphically depicted in Figure 1.

\section{Experimental details}

\section{Treatment details}

The experiment was laid out in split plot design with 12 treatment combinations comprising of three tillage treatments; $\mathrm{T}_{1}$ - 
zero tillage (ZT), $\mathrm{T}_{2}$ - permanent bed $(\mathrm{PB})$ and T3- conventional tillage (CT), in main plot, four rabi crops viz. $\mathrm{C}_{1}$ - Rabi Maize (var. $\mathrm{P}$ 3396), $\mathrm{C}_{2^{-}}$Wheat (var. HD 2967), $\mathrm{C}_{3^{-}}$ Mustard (var. JG 14) and $\mathrm{C}_{4}$-Chickpea (var. Rajendra Suphlam) in sub plot. The fertilizer dose was 150:75:50, 120:60:40, 20:50: 0, 80:40:40 ( $\left.\mathrm{N}: \mathrm{P}_{2} \mathrm{O}_{5}: \mathrm{K}_{2} \mathrm{O} \mathrm{kgha}^{-1}\right)$, respectively. Nitrogen was applied in three splits, half as a basal dose at the time of sowing, one fourth before first irrigation and one fourth before third irrigation while full dose of $\mathrm{P}_{2} \mathrm{O}_{5}$ and $\mathrm{K}_{2} \mathrm{O}$ were applied as basal. Before sowing of crop in the plots a uniform application of pre emergence herbicide - Pendimethalin @ 3L a.i. ha ${ }^{-1}$ was sprayed for management of weeds and the crop was sown two days after application of herbicide.

In zero tillage, crops were grown on zero tilled plots without disturbing the soil except for seed or fertilizer placement, with 30 per cent maize residue retained in the plots from the earlier maize crop in rotation. The conventional tilled plots were ploughed with two passes of tractor drawn disc plough followed by two ploughing with cultivator and one planking. The field was uniformly leveled to the specified plot dimension and impermanent bed, crops were grown on permanent bed plots without disturbing the soil except for seed or fertilizer placement, with 30 per cent maize residue retained in the plots from the earlier maize crop in rotation. The width of the beds (mid-furrow to midfurrow) was $67 \mathrm{~cm}$, with $37 \mathrm{~cm}$ wide flat tops, and $30 \mathrm{~cm}$ furrow width. The prices in rupees of the inputs that were prevailing at the time of their use were considered for working out the cost of cultivation. Net returns $\mathrm{ha}^{-1}$ were calculated by deducting the cost of cultivation $\mathrm{ha}^{-1}$ from gross income. To interpret the effect of different treatments, the data collected in course of experiment were analyzed statistically by applying the analysis of variance techniques laid down by Cochran and
Cox (1967), Panse and Sukhatme (1978) and Gomez and Gomze (1984). Relevant data were statistically analyzed separately to interpret the results and the mean data for each parameter has been presented. For comparison of ' $F$ ' values and for determination of critical difference at 5\% level of significance, Fischer and Yates Table (1963) were consulted.

\section{Results and Discussion}

\section{Effect of different tillage practices on total biological yield and grain yield of different crops}

The data of biological yield and grain yield of different rabi crops has been presented in the table 1. The total biological yield showed variable response in different crops due to alteration in tillage practices. In wheat due to tillage practices biological yield was significantly higher with PB over CT. The maximum biological yield was recorded in PB (14132 $\mathrm{kg} \mathrm{ha}^{-1}$ ) which was significantly higher as compared to CT (12017 kg ha $\left.{ }^{-1}\right)$ but biological yield in ZT wheat (13339 $\mathrm{kg} \mathrm{ha}^{-1}$ ) was at par with both PB and CT. In maize biological yield in ZT (25359 $\mathrm{kg} \mathrm{ha}^{-1}$ ) was significantly higher with CT (22262 kg ha ${ }^{-1}$ ) and biological yield in PB (23786 kg ha-1) was statistically at par with ZT as well as CT. In mustard there was no significant effect of tillage practices on biological yield. The maximum biological yield was recorded in CT (4255 $\mathrm{kg} \mathrm{ha}^{-1}$ ) which was statistically at par with ZT (3906 kg ha-1) and PB (3875 kg ha-1). In chickpea also there was no significant effect of tillage practices on biological yield. However, the maximum biological yield was recorded in ZT (5194 $\left.\mathrm{kg} \mathrm{ha}^{-1}\right)$ which was statistically at par with CT (5020 kg ha $\left.{ }^{-1}\right)$ and PB (4822 kg ha ${ }^{-1}$ ).

In wheat the maximum grain yield was recorded in $\mathrm{PB}$ (5488 $\mathrm{kg} \mathrm{ha}^{-1}$ ) which was significantly higher as compared to CT (4442 
$\mathrm{kg} \mathrm{ha}^{-1}$ ) and statistically at par with ZT grain yield $\left(5463 \mathrm{~kg} \mathrm{ha}^{-1}\right)$. The grain yield was $19.1 \%$ and $18.7 \%$ higher in PB and ZT as compared to $\mathrm{CT}$ plots respectively. In maize the grain yield was significantly higher with ZT (11279 kg ha ${ }^{-1}$ ) over CT (9427 kg ha $\left.{ }^{-1}\right)$. The grain yield of maize in PB (10863 $\left.\mathrm{kg} \mathrm{ha}^{-1}\right)$ was found statistically at par with ZT. The grain yield was $16.4 \%$ and $13.2 \%$ higher in ZT and $\mathrm{PB}$ as compared to $\mathrm{CT}$ plots respectively. In mustard there was no significant effect of tillage on grain yield.

However, maximum grain yield was recorded in ZT (970 kg ha ${ }^{-1}$ ) which was statistically at par with PB (955 kg ha ${ }^{-1}$ ) and CT (931 kg $\left.\mathrm{ha}^{-1}\right)$. The grain yield was $4.0 \%$ and $2.5 \%$ higher in ZT and PB as compared to CT plots respectively. In chickpea there was significant effect of ZT on grain yield as compared to PB and CT. The maximum grain yield was recorded in ZT (1936 $\mathrm{kg} \mathrm{ha}^{-1}$ ) which was significantly higher over PB (1790 kg ha $\left.{ }^{-1}\right)$ and CT (1705 kg ha-1). The PB and CT crops produced almost similar yields while ZT plots produced $8 \%$ and $13 \%$ higher yield over $\mathrm{PB}$ and CT plots respectively.

The tillage had significant influence in straw yield of wheat only and there was no significant effect of tillage was found in stover yield of maize and straw yield of mustard and chickpea. In wheat straw yield was significantly higher in PB (8644 $\left.\mathrm{kg} \mathrm{ha}^{-1}\right)$ over CT $\left(7575 \mathrm{~kg} \mathrm{ha}^{-1}\right)$. The straw yield in $\mathrm{ZT}$ $\left(7876 \mathrm{~kg} \mathrm{ha}^{-1}\right)$ was found statistically at par with PB as well as CT. In maize the maximum stover yield was recorded in ZT $(14080 \mathrm{~kg}$ $\mathrm{ha}^{-1}$ ) which was statistically at par with CT (12835 kg ha ${ }^{-1}$ ) and PB (12923 kg ha $\left.{ }^{-1}\right)$. In mustard the maximum straw yield was recorded in CT (4175 $\mathrm{kg} \mathrm{ha}^{-1}$ ) which was statistically at par with ZT (3718 $\left.\mathrm{kg} \mathrm{ha}^{-1}\right)$ and PB (3695 kg ha ${ }^{-1}$ ). In chickpea the maximum straw yield was recorded in CT (3314 $\left.\mathrm{kg} \mathrm{ha}^{-1}\right)$ which was statistically at par with ZT (3259 $\mathrm{kg} \mathrm{ha}^{-1}$ ) and PB (3032 $\left.\mathrm{kg} \mathrm{ha}^{-1}\right)$. Zero tillage had a significant influence in increasing the crop yield followed by permanent bed.

Due to early sowing under zero tillage and permanent bed condition resulted in early establishment of the crop and consecutive higher dry matter accumulation. The reduction in tillage is expected to result in a progressive change in the total porosity of soil and also consecutive changes in bulk density. However due to increased porosity the water capacity of the soil is increased with ZT and PB as a result the plant can utilize the major proportion of soil moisture for its growth and development. The reduction in tillage is expected to result in a progressive change in the total porosity of soil and also consecutive changes in bulk density. Considering the final biomass at harvest, wheat recorded significantly higher biomass under PB (14132 $\left.\mathrm{kg} \mathrm{ha}^{-1}\right)$ over conventional tillage (12017 kg ha-1) while in maize it was significantly higher under ZT (25359 $\mathrm{kg} \mathrm{ha}^{-1}$ ) than CT.

The positive effect of $\mathrm{ZT}$ and $\mathrm{PB}$ on grain yields of all the rabi crops (wheat, maize mustard and chickpea) was found in this experiment. All yield component of wheat, maize, mustard and chickpea was significantly higher in ZT compared to CT. Ultimately significant higher value of yield attributes of these four rabi crops were positively related to grain yield of the crops but grain yield of wheat was found significantly higher under PB whereas in rabi maize and chickpea yield was significantly higher in ZT. The results are in consistent with earlier studies from South Asia which showed higher crop yields under ZT compared to $\mathrm{CT}$ in rice-wheat and maizewheat systems (Jat et al., 2013; Gathala et al., 2013; Singh et al., 2016).The significantly higher wheat grain was recorded in the PB plots compared with CT plots, which could be attributed to the higher spike density, number of grains per spike and 1000-grain weight. 
Fig.1 Weather condition during experimental season (2017-18)

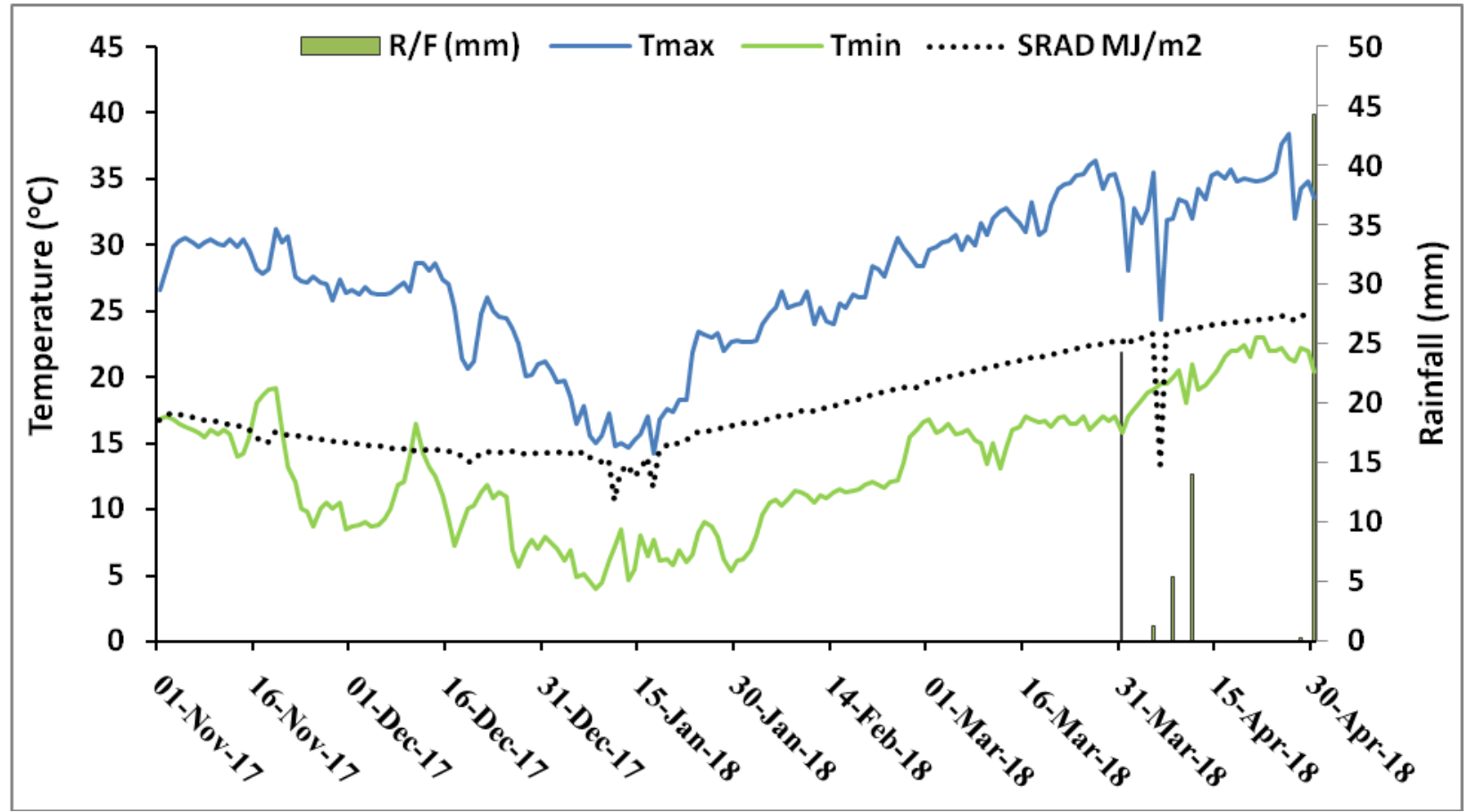

Table.1 Biological, grain, straw yield and harvest index of rabi crops as influenced by tillage methods

\begin{tabular}{|c|c|c|c|c|}
\hline $\begin{array}{c}\text { Rabi } \\
\text { crops/ } \\
\text { Tillage }\end{array}$ & $\begin{array}{c}\text { Biological } \\
\text { Yield } \\
\left(\mathrm{kg} \mathrm{ha}^{-1}\right)\end{array}$ & $\begin{array}{c}\text { Grain yield } \\
\left(\mathrm{Kg} \mathrm{ha}^{-1}\right)\end{array}$ & $\begin{array}{l}\text { Straw/ Stover } \\
\text { yield }\left(\mathrm{kg} \mathrm{ha}^{-1}\right)\end{array}$ & $\begin{array}{c}\text { Harvest } \\
\text { Index }(\%)\end{array}$ \\
\hline \multicolumn{5}{|l|}{ Wheat } \\
\hline ZT & $13339 \mathrm{ab}$ & $5463 \mathrm{a}$ & $7876 \mathrm{ab}$ & $41 \mathrm{a}$ \\
\hline CT & $12017 \mathrm{~b}$ & $4442 \mathrm{~b}$ & $7575 \mathrm{~b}$ & $37 \mathrm{~b}$ \\
\hline PB & $14132 \mathrm{a}$ & $5488 \mathrm{a}$ & $8644 a$ & $39 a b$ \\
\hline \multicolumn{5}{|l|}{ Maize } \\
\hline ZT & $25359 a$ & $11279 \mathrm{a}$ & $14080 \mathrm{a}$ & $45 \mathrm{a}$ \\
\hline CT & $22262 b$ & $9427 \mathrm{~b}$ & $12835 \mathrm{a}$ & $42 \mathrm{a}$ \\
\hline PB & $23786 a b$ & $10863 \mathrm{a}$ & 12923 a & $46 a$ \\
\hline \multicolumn{5}{|l|}{ Mustard } \\
\hline ZT & $4687 \mathrm{a}$ & $970 \mathrm{a}$ & $3718 a$ & $21 \mathrm{a}$ \\
\hline CT & $5106 \mathrm{a}$ & $931 \mathrm{a}$ & $4175 \mathrm{a}$ & $18 \mathrm{~b}$ \\
\hline PB & $4650 \mathrm{a}$ & $955 \mathrm{a}$ & $3695 \mathrm{a}$ & $21 \mathrm{a}$ \\
\hline \multicolumn{5}{|l|}{ Chickpea } \\
\hline ZT & $5194 \mathrm{a}$ & $1936 \mathrm{a}$ & $3259 a$ & $37 \mathrm{a}$ \\
\hline CT & $5020 \mathrm{a}$ & $1705 \mathrm{~b}$ & $3314 a$ & $34 \mathrm{~b}$ \\
\hline PB & $4822 \mathrm{a}$ & $1790 \mathrm{~b}$ & $3032 \mathrm{a}$ & $37 \mathrm{a}$ \\
\hline
\end{tabular}


Table.2 Equivalent yield and economics of rabi crops as influenced by tillage methods

\begin{tabular}{|c|c|c|c|c|c|}
\hline Treatment & $\begin{array}{c}\text { Wheat } \\
\text { equivalent } \\
\text { yield } \\
\left(\mathrm{kg} \mathrm{ha}^{-1}\right)\end{array}$ & $\begin{array}{c}\text { Cost of } \\
\text { cultivation } \\
\left(\text { Rs. ha }{ }^{-1}\right)\end{array}$ & $\begin{array}{c}\text { Gross } \\
\text { return } \\
\left(\text { Rs. ha } \mathbf{h}^{-1}\right)\end{array}$ & $\begin{array}{c}\text { Net } \\
\text { return } \\
\left(\text { Rs. ha }{ }^{-1}\right)\end{array}$ & $\begin{array}{l}\text { B.C. } \\
\text { ratio }\end{array}$ \\
\hline \multicolumn{6}{|l|}{ Tillage } \\
\hline Zero Tillage & 5468 & 30083 & 94862 & 64779 & 2.09 \\
\hline $\begin{array}{c}\text { Conventional } \\
\text { Tillage }\end{array}$ & 4664 & 34295 & 80917 & 46622 & 1.33 \\
\hline Permanent Bed & 5288 & 29954 & 91743 & 61789 & 2.02 \\
\hline S Em $( \pm)$ & 138 & & 2396 & 2396 & 0.08 \\
\hline C.D at $5 \%$ & 542 & & 9406 & 9406 & 0.31 \\
\hline \multicolumn{6}{|l|}{ Rabi Crops } \\
\hline Wheat & 5131 & 32767 & 89022 & 56255 & 1.74 \\
\hline Rabi Maize & 8643 & 49441 & 149950 & 100509 & 2.05 \\
\hline Mustard & 2194 & 21892 & 38073 & 16181 & 0.77 \\
\hline Chickpea & 4591 & 21675 & 79650 & 57975 & 2.70 \\
\hline $\operatorname{SEm}( \pm)$ & 90 & & 1567 & 1567 & 0.06 \\
\hline C.D at $5 \%$ & 268 & & 4655 & 4655 & 0.19 \\
\hline \multicolumn{6}{|l|}{ Interaction } \\
\hline ZT-W & 5463 & 31029 & 94782 & 63753 & 2.05 \\
\hline ZT-M & 9264 & 47437 & 160724 & 113288 & 2.39 \\
\hline ZT-Mu & 2235 & 20887 & 38780 & 17893 & 0.86 \\
\hline ZT-C & 4908 & 20980 & 85162 & 64182 & 3.06 \\
\hline CT-W & 4442 & 35597 & 77069 & 41473 & 1.17 \\
\hline CT-M & 7742 & 51811 & 134330 & 82519 & 1.59 \\
\hline CT-Mu & 2146 & 25849 & 37240 & 11391 & 0.44 \\
\hline CT-C & 4324 & 23923 & 75029 & 51106 & 2.14 \\
\hline PB-W & 5488 & 31677 & 95216 & 63539 & 2.01 \\
\hline PB-M & 8922 & 49074 & 154796 & 105722 & 2.15 \\
\hline PB-Mu & 2202 & 18940 & 38200 & 19260 & 1.02 \\
\hline PB-C & 4539 & 20123 & 78760 & 58637 & 2.91 \\
\hline $\operatorname{SEm}( \pm)$ & 156.39 & & 3356 & 3356 & 0.12 \\
\hline C.D at $5 \%$ & 464.66 & & 9970 & 9970 & NS \\
\hline
\end{tabular}

ZT-Zero tillage; CT-Conventional tillage; PB-Permanent bed; W-Wheat; M-Maize-; Mus-Mustard; C-Chickpea

The present findings are well supported by Dhillon et al., (2000) and Hobbs and Gupta (2003) who also reported higher yields of wheat in bed-planted wheat than flat-planted wheat. The significantly higher yield of maize and chickpea in ZT system could be due to the compound effects of additional nutrients
(Blanco-Canqui and Lal, 2009; Kaschuk et al., 2010), lesser weed population (Ozpinar, 2006; Chauhan et al., 2007), improved soil physical health (Jat et al., 2013; Singh et al., 2016), better water regimes (Govaerts et al., 2009) and improved nutrient use efficiency compared to CT (Unger and Jones, 1998). In 
addition to all these factors, the root growth found better under CA compared to CT due to lesser compaction (Passioura, 2002; BlancoCanqui et al., 2006). The harvest index showed variable response in different crops due to alteration in tillage practices (Table 1). In wheat maximum harvest index was recorded in ZT (41\%) which was significantly higher as compared to CT $(37 \%)$. The harvest index in PB (39\%) was found statistically at par with ZT as well as CT. In maize there was no significant difference in harvest index due to tillage practices. However, the maximum harvest index was recorded in PB $(46 \%)$ which was statistically at par with ZT (45\%) and CT (42\%). In mustard maximum harvest index was recorded under ZT (21\%) and PB $(21 \%)$ which was significantly higher over CT (18\%). In chickpea maximum harvest index was recorded in ZT (37\%) and PB (37\%) which was significantly higher over CT (34\%).

\section{Wheat equivalent yield}

There was significant influence of tillage, rabi crops and their interaction on wheat equivalent yield (Table 1). In main plot due to tillage practices wheat equivalent yield was significantly higher in ZT (5468 $\left.\mathrm{kg} \mathrm{ha}^{-1}\right)$ over CT (4664 kg ha ${ }^{-1}$ ) while wheat equivalent yield in PB (5288 $\mathrm{kg} \mathrm{ha}^{-1}$ ) was statistically at par with ZT. In sub plot due to rabi crops wheat equivalent yield was significantly higher in rabi maize (8643 $\mathrm{kg} \mathrm{ha}^{-1}$ ) over wheat $\left(5131 \mathrm{~kg} \mathrm{~h}^{-1}\right)$, chickpea $\left(2194 \mathrm{~kg} \mathrm{ha}^{-1}\right)$ and mustard $\left(4591 \mathrm{~kg} \mathrm{ha}^{-1}\right)$. The interaction effect of tillage and rabi crops was differed significantly, where wheat equivalent yield was at par in ZT-maize (9264 $\mathrm{kg} \mathrm{ha}^{-1}$ ) and PB-maize (8922 kg ha ${ }^{-1}$ ) but significantly higher compared to rest of the interaction.

The wheat equivalent yield was $14.7 \%$ and $11.8 \%$ higher in ZT and $\mathrm{PB}$ as compared to CT plots respectively. The lowest wheat equivalent yield was recorded in mustard crop irrespective of tillage systems.

\section{Effect of different tillage practices on economics}

Economics of rabi crops was significantly influenced by different tillage methods and rabi crops. The cost of cultivation for different rabi crops was almost similar in PB (Rs. $29954 \mathrm{ha}^{-1}$ ) and ZT (Rs. $30083 \mathrm{ha}^{-1}$ ) but was lower than CT (Rs. $34295 \mathrm{ha}^{-1}$ ). As a result, the net return and benefit cost ratio (B: $\mathrm{C}$ ratio) was significantly higher with $\mathrm{ZT}$ and PB over CT (Table 2).

Due to tillage practices the maximum net return and B: C ratio of Rs. $64779 \mathrm{ha}^{-1}$ and 2.07 respectively was recorded with $\mathrm{ZT}$ which was significantly higher over CT (Rs. 46622 $\mathrm{ha}^{-1}$ and 1.33) while statistically at par with PB (Rs. $61789 \mathrm{ha}^{-1}$ and 2.02). Among rabi crops maximum net return Rs. $100509 \mathrm{ha}^{-1}$ was recorded in rabi maize which was significantly higher as compared to other rabi crops but chickpea recorded maximum B: C ratio (2.70) which was significantly higher over other rabi crops. Interactions between tillage and rabi crops showed significant influence on gross return, net return and B: C ratio. ZT-maize (Rs. $160724 \mathrm{ha}^{-1}$ ) recorded significantly higher gross return as compared to CT-maize (Rs $134330 \mathrm{ha}^{-1}$ ) while gross return in PB-maize (Rs. 154796 ha $^{-1}$ ) was statistically at par with ZT-maize. Gross return of wheat was found significantly higher in PB-wheat (Rs. 95216 ha $^{-1}$ ) over CT-wheat (Rs $77069 \mathrm{ha}^{-1}$ ) while statistically at par with ZT-wheat (Rs. 94782 ha $^{-1}$ ). Gross return of chickpea was found significantly higher in ZT-chickpea (Rs. $85162 \mathrm{ha}^{-1}$ ) over CTchickpea (Rs $75029 \mathrm{ha}^{-1}$ ) while statistically at par with PB-chickpea (Rs. $78760 \mathrm{ha}^{-1}$ ).

Tillage practices contribute significantly to the labour cost as well as land preparation 
cost for any crop production system resulting in lower economic returns (Gowing and Palmer, 2008). The return compared to the investment was much higher with $\mathrm{ZT}$ system compared to the CT system. In the present experiment due to $\mathrm{ZT}$ and $\mathrm{PB}$ the cost of cultivation reduced by 12.3 and 12.6 per cent and gave 28 and 24 per cent higher net return as compared to $\mathrm{CT}$, respectively. The $\mathrm{B}$ : $\mathrm{C}$ ratio was 36.6 and 34.1per cent higher in $\mathrm{ZT}$ and $\mathrm{PB}$ as compared to $\mathrm{CT}$ respectively. The higher net return and $\mathrm{B}$ : $\mathrm{C}$ ratio in $\mathrm{ZT}$ and $\mathrm{PB}$ were attributed mainly to lower cost of cultivation and the higher yield levels which eventually led to the increase in net return over CT. On average more than half of the benefits were due to cost savings and the rest part was mainly due to yield increase with ZT system. These increments in net returns were mainly due to non- requirement of preparatory tillage unlike in CT where 4-5 tillage operations were performed before sowing of crops. Similar results pertaining to the tillage system were also reported by many researchers (Yadav et al., 2017; Parihar et al., 2016; Singh et al., 2014).

The grain yield of wheat obtained under PB and ZT was $19.1 \%$ and $18.7 \%$ higher than CT respectively. The grain yield of maize was $16.4 \%$ and $13.2 \%$ higher in $\mathrm{ZT}$ and $\mathrm{PB}$ as compared to $\mathrm{CT}$ plots respectively. The mustard crop under $\mathrm{PB}$ and $\mathrm{CT}$ produced almost similar yields while ZT plots produced $8 \%$ and $13 \%$ higher yield over PB and CT plots respectively. Tillage methods showed significant effect on straw yield of wheat crop only, which was maximum and $12.36 \%$ higher under $\mathrm{PB}$ as compared to $\mathrm{CT}$. The harvest index (H.I.) of wheat, mustard and chickpea were $9.8 \%, 14.28 \%$ and $8.1 \%$ higher under ZT than $\mathrm{CT}$. The wheat equivalent yield was $14.7 \%$ and $11.8 \%$ higher in $\mathrm{ZT}$ and $\mathrm{PB}$ as compared to $\mathrm{CT}$ plots respectively. Among rabi crops maize equivalent yield was found maximum in rabi maize followed by wheat, chickpea and mustard. ZT and PB resulted in $12.3 \%$ and $12.5 \%$ lower cost of cultivation while $28.0 \%$ and $24.5 \%$ higher net return over CT respectively. Among rabi crops highest net return was found in maize followed by chickpea. B: C ratio was $36.6 \%$ and $34.1 \%$ higher in $\mathrm{ZT}$ and $\mathrm{PB}$ over $\mathrm{CT}$ respectively. Among rabi crops maximum $\mathrm{B}$ : $\mathrm{C}$ ratio was recorded in chickpea (2.70) followed by maize (2.05).

Based on one-year data of experiment it can be concluded that the conservation agriculture-based zero tillage and permanent bed tillage practices along with residue retention resulted in significant increase in total biological yield, grain production and productivity of rabi crops with higher net returns and $\mathrm{B}: \mathrm{C}$ ratio than conventional tillage. The overall improvement in soil condition resulted in higher wheat equivalent yield (WEY) of rabi crops especially in wheat followed by maize, chickpea while the least increase in WEY was recorded in mustard as compared to conventionally tilled rabi crops.

With all these evidence we can say that zero tillage along with partial residue retention can be adopted for sustainable and profitable cropping in the region.

\section{References}

Ali, M. Y., Waddington, S. R., Timsina, J., Hodson, D. P., and Dixon, J. (2009). Maize-rice cropping systems in Bangladesh: status and research needs. Journal of Agricultural Science and Technology, 3(6), 35-53.

Aryal A, Brooks BA, Reid ME (2015) Landslide subsurface slip geometry inferred from 3- D surface displacement fields. Geophysical Research Letters 42(5):1411-7.

Bhushan B, Jung YC (2008) Wetting, adhesion and friction of 
superhydrophobic and hydrophilic leaves and fabricated micro/ nanopatterned surfaces. Journal of Physics: Condensed Matter 20(22): 225010.

Blanco-Canqui H, Lal R (2009) Crop residue removal impacts on soil productivity and environmental quality. Critical reviews in plant science 28(3): 139-63.

Blanco-Canqui H, Lal R, Post WM, Owens LB (2006) Changes in long-term no-till corn growth and yield under different rates of stover mulch. Agronomy journal 98(4): 1128-36.

Chauhan BS, Gill GS, Preston C (2007) Effect of seeding systems and dinitroaniline herbicides on emergence and control of rigid ryegrass (Lolium rigidum) in wheat. Weed Technology 21(1): 53-8.

Cochran, G.W. and Cox, M.G. (1967). Experimental Design. John Willey and Sons, Inc. U.S.A.

Dhillon SS. Investigations on bed planting system as an alternative tillage and crop establishment practice for improving wheat yields sustainably. In Proceedings of the 15th Conference of the International Soil Tillage Research Organisation'2-7 July 2000, Fort Worth, Texas 2000.

Fischer, R. A. and Yates, F. (1963). Statistical Tables for Biological Agricultural and Medical Research (6 ${ }^{\text {th }}$ Ed.). Oliver and Boyd, Edinburgh, Tweeddale Cowot, London.

Gathala MK, Kumar V, Sharma PC, Saharawat YS, Jat HS, Singh M, Kumar A, Jat ML, Humphreys E, Sharma DK, Sharma S (2013) Optimizing intensive cereal-based cropping systems addressing current and future drivers of agricultural change in the northwestern Indo-Gangetic Plains of India. Agriculture, Ecosystems \& Environment 177: 85-97.
Gathala MK, Ladha JK, Saharawat YS, Kumar V, Kumar V, Sharma PK (2011) Effect of tillage and crop establishment methods on physical properties of a medium-textured soil under a sevenyear rice- wheat rotation. Soil Science Society of America Journal 75(5): 1851-62

Gill NK, Appleton M, Baganz F, Lye GJ (2008) Quantification of power consumption and oxygen transfer characteristics of a stirred miniature bioreactor for predictive fermentation scale- up. Biotechnology and bioengineering 100(6): 1144-55.

Gomez, K. A., and Gomez, A. A. (1984). Statistical procedures for agricultural research. John Wiley \& Sons.

Govaerts B, Sayre KD, Goudeseune B, De Corte P, Lichter K, Dendooven L, Deckers J (2009) Conservation agriculture as a sustainable option for the central Mexican highlands. Soil and Tillage Research 103(2): 222-30.

Gowing JW, Palmer M (2008) Sustainable agricultural development in sub- Saharan Africa: the case for a paradigm shift in land husbandry. Soil use and management 24(1): 92-9.

Hassan AN, Awad S, Muthukumarappan K (2005) Effects of exopolysaccharideproducing cultures on the viscoelastic properties of reduced-fat Cheddar cheese. Journal of dairy science $88(12)$ : 4221-7.

Hassan, I., Hussain, Z., and Akbar, G. (2005). Effect of permanent raised beds on water productivity for irrigated maizewheat cropping system. Evaluation and performance of permanent raised bed cropping systems in Asia, Australia and Mexico. ACIAR Proceeding, (121).

Hobbs PR, Gupta RK (2003) Resourceconserving technologies for wheat in the rice-wheat system. Improving the productivity and sustainability of rice- 
wheat systems: Issues and impacts.14971.

Jat ML, Gathala MK, Ladha JK, Saharawat YS, Jat AS, Kumar V, Sharma SK, Kumar V, Gupta R (2009) Evaluation of precision land leveling and double zerotill systems in the rice-wheat rotation: Water use, productivity, profitability and soil physical properties. Soil and Tillage Research 105(1): 112-21.

Jat ML, Gathala MK, Saharawat YS, Tetarwal JP, Gupta R (2013) Double no-till and permanent raised beds in maize-wheat rotation of north-western Indo-Gangetic plains of India: Effects on crop yields, water productivity, profitability and soil physical properties. Field Crops Research 149: 291-9

Jat RA, Wani SP, Sahrawat KL (2012) Advances in agronomy Conservation agriculture in the semi-arid tropics: prospects and problems. Academic Press.

Jat RK, Sapkota TB, Singh RG, Jat ML, Kumar M, Gupta RK (2014) Seven years of conservation agriculture in a rice-wheat rotation of eastern Gangetic Plains of South Asia: yield trends and economic profitability. Field Crops Research 164: 199-210.

Kaschuk, G., Alberton, O., Hungria, M., 2010. Three decades of soil microbial biomass studies in Brazilian ecosystems: lessons learned about soil quality and indications for improving sustainability. Soil Biol. Biochem. 42, $1-13$.

Ozpinar S. Effects of tillage systems on weed population and economics for winter wheat production under the Mediterranean dryland conditions. Soil and Tillage Research. 2006 May 1; 87(1): 1-8.

Pandey BP, Vranjes J, Krishan V (2008) Waves in the solar photosphere. Monthly Notices of the Royal
Astronomical Society 386(3): 1635-43.

Panse, V. G., \& Sukhatme, P. V. (1954). Statistical methods for agricultural workers. Statistical methods for agricultural workers.

Parihar CM, Yadav MR, Jat SL, Singh AK, Kumar B, Pradhan S, Chakraborty D, Jat ML, Jat RK, Saharawat YS, Yadav OP (2016) Long term effect of conservation agriculture in maize rotations on total organic carbon, physical and biological properties of a sandy loam soil in north-western IndoGangetic Plains. Soil and Tillage Research 161: 116-28.

Passioura JB (2002) Soil conditions and plant growth. Plant, Cell \& Environment 25(2): 311-8.

Singh VK, Dwivedi BS, Singh SK, Majumdar K, Jat ML, Mishra RP, Rani M (2016) Soil physical properties, yield trends and economics after five years of conservation agriculture based ricemaize system in north-western India. Soil and Tillage Research 155: 133-48.

Singh VK, Dwivedi BS, Tiwari KN, Majumdar K, Rani M, Singh SK, Timsina J (2014) Optimizing nutrient management strategies for rice-wheat system in the Indo-Gangetic Plains of India and adjacent region for higher productivity, nutrient use efficiency and profits. Field Crops Research 164: 3044.

Six J, Conant RT, Paul EA, Paustian K (2002) Stabilization mechanisms of soil organic matter: implications for Csaturation of soils. Plant and soil 241(2): 155-76.

Six, J., Conant, R. T., Paul, E. A., and Paustian, K. (2002). Stabilization mechanisms of soil organic matter: implications for C-saturation of soils. Plant and soil, 241(2), 155-176.

Stocking M, Murnaghan N, London-Sterling VA (2001) Handbook for the Field 
Assessment of Land Degradation. Earthscan Pub. Ltd., London-Sterling, VA, USA.

Unger PW, Jones OR (1998) Long-term tillage and cropping systems affect bulk density and penetration resistance of soil cropped to dryland wheat and grain sorghum. Soil and tillage research 45(12): 39-57.

Yadav MR, Parihar CM, Jat SL, Singh AK, Kumar R, Yadav RK, Kuri BR, Parihar
MD, Yadav B, Verma AP, Jat ML (2017) Long term effect of legume intensified crop rotations and tillage practices on productivity and profitability of maize vis-a-vis soil fertility in North-Western IndoGangetic Plains of India. Legume Research: An International Journal 40(2).

\section{How to cite this article:}

Shweta Kumari, Sanjay Kumar, Asheesh Chaurasiya, Swaraj Kumar Dutta, Amit Pradhan and Subrat Keshori Behera. 2019. Conservation Agriculture Based Tillage Options for Rabi Crops Cultivation in Eastern India: Effects on Productivity and Profitability. Int.J.Curr.Microbiol.App.Sci. 8(07): 1678-1689. doi: https://doi.org/10.20546/ijcmas.2019.807.199 